\title{
A Polícia e o Medo do Crime no Distrito Federal
}

\author{
Arthur Trindade Maranhão Costa ${ }^{1}$ \\ Marcelo Ottoni Durante ${ }^{2}$ \\ ${ }^{1}$ Professor associado da Universidade de Brasília e Coordenador do Núcleo de Estudos sobre Violência e \\ Segurança (NEVIS/UnB). Brasília, DF. Brasil. \\ E-mail: arthurtmcosta@gmail.com, https:/ / orcid.org/0000-0002-1427-4622 \\ 2 Professor adjunto III da Universidade Federal de Viçosa (UFV). Viçosa, MG. Brasil. \\ E-mail: modurante71@gmail.com, https:/ / orcid.org/0000-0002-9048-1834
}

\section{INTRODUÇÃO}

$\mathrm{O}$ $\mathrm{s}$ estudos mostram que, ao contrário do que supõe o senso comum, o medo do crime e a vitimização não necessariamente estão associados (Hale, 1996). Essa relação depende do tipo de crime e do número de vezes que a pessoa foi vitimada. Pessoas que foram vítimas de crimes violentos ou que foram vítimas de vários crimes tendem a sentir mais medo (Gray et al., 2008; Tseloni e Zarafonitou, 2008). Além desses aspectos, é preciso também considerar a vitimização indireta. Quando a vítima é um membro da família (ou alguém com fortes laços afetivos), a associação entre vitimização e medo do crime tende a ser muito mais forte (Warr e Ellison, 2000). No entanto, cabe salientar que o medo do crime não é delimitado apenas pela vitimização, seja direta ou indireta.

A constatação de que há pouca relação entre estes dois fenômenos fez com que os pesquisadores buscassem entender os principais fatores explicativos do medo do crime, bem como analisar seus impactos na qualidade de vida das pessoas. Outros fatores contribuem para aumentar o medo do crime. $\mathrm{O}$ ambiente urbano impacta significativamente no medo. Os moradores de lugares com desordens (prédios e carros abandonados, terrenos baldios, com lixo acumulado etc.) e incivilidades (pichações, prostituição, brigas, som alto etc.) tendem a sentir mais medo. A qualidade dos serviços públicos também afeta a sensação de segurança. Isso é especialmente válido para os serviços de transporte, iluminação e fiscalização do trânsito. Além da vitimização, do ambiente urbano e da qualidade dos serviços públicos, há

DADOS, Rio de Janeiro, vol.62(1):e20180032, 2019.

http://dx.doi.org/10.1590/001152582019172 
um outro fator que afeta consideravelmente o medo do crime: a presença, confiança e satisfação com a atuação da polícia.

De forma geral, a literatura sobre o medo do crime tem buscado explicar o fenômeno a partir de duas categorias. Na primeira categoria, há uma ênfase nos aspectos que aumentam o medo, tais como vulnerabilidades físicas, sociais, desordens e desorganização social. A segunda, se concentra na análise dos aspectos que reduzem o medo: laços sociais, vínculos comunitários, coesão social e eficácia coletiva (Franklin e Franklin, 2009).

Alguns dos debates concentram-se em analisar as vulnerabilidades que podem ser físicas ou sociais (Schafer et al., 2006; Goodey, 1997). As primeiras referem-se à percepção do risco de sofrer algum tipo de violência em função de desvantagens físicas relacionadas à falta de mobilidade, força ou competência. Já as vulnerabilidades sociais estão relacionadas às condições sociais de moradia, educação e renda (Cohen e Felson, 1979; Killias e Clerici, 2000; Pantatzis, 2000; Franklin e Franklin, 2009). Outros estudos sugerem que há forte associação entre as condições de vida, o ambiente social e a sensação de insegurança (Sacco, 1993; Sampson e Groves, 1989). O local de residência impactaria no medo do crime em função de dois aspectos: a existência na vizinhança de desordens e incivilidades, e a coesão social.

Além de analisar os principais fatores relacionados ao medo, os estudos também têm procurado avaliar qual é o efeito das atividades do Estado (especialmente das polícias) na percepção de medo da população (Bennett, 1991; Hawdon et al., 2003; Scheider et al., 2003). Qual o papel da polícia em relação ao medo do crime? Esta é uma das perguntas mais relevantes nos estudos que buscam entender o medo.

No Brasil, as pesquisas sobre medo do crime e suas consequências ainda são incipientes. Em geral são estudos etnográficos sobre como a "fala do crime" é construída e afeta o cotidiano das famílias (Caldeira, 2000; Machado, Borges e Moura, 2014). Ainda são poucos os estudos baseados em surveys e que permitem comparabilidade (Beato Filho et al., 2008; Borges, 2011; Oliveira, 2011; Silva e Beato Filho, 2013; Rodrigues e Oliveira, 2013; Oliveira e Alencar, 2015). Este artigo explora a relação entre as percepções que as pessoas têm sobre a atuação da polícia e o medo delas em relação ao crime. A atuação da polícia foi avaliada a partir das seguintes dimensões: (a) presença e qualidade do 
policiamento, (b) a atuação da polícia, (c) a qualidade da conduta dos policiais e do serviço prestado e (d) a violência policial.

\section{A POLÍCIA E O MEDO DO CRIME}

As pesquisas têm apontado que as polícias desempenham papel importante na redução do medo (Hale, 1996). A simples presença da polícia nas ruas pode ser suficiente para aumentar a sensação de segurança. Exatamente por isso, a saturação de área é a estratégia mais frequentemente utilizada para promover uma sensação de segurança. Entretanto, embora seja relativamente bem-sucedida, este tipo de estratégia de policiamento tem sérias limitações de tempo e espaço. Ela não pode ser empregada por muito tempo e tampouco pode ser aplicada a todos os bairros. Normalmente são os bairros mais ricos que recebem este tipo de policiamento por tempo limitado. Por estes motivos, a saturação de área tem sido apontada como uma estratégia excludente, pois reforça as desigualdades sociais (Bennett, 1991; Winkel, 1988).

As iniciativas que conseguiram maior sucesso na redução do medo foram aquelas que aumentaram a presença física de policiais e que buscaram maior envolvimento da polícia na vida das comunidades. Estas iniciativas incluem policiamento a pé, acompanhamento das vítimas, realização de reuniões e apresentação de relatórios para a comunidade, instalação de postos policiais e realização de visitas às residências (Trajanowics, 1986; Goldstein, 1990).

Sem dúvida, independente da estratégia de policiamento, as polícias têm papel central na redução do medo: reduzindo a frequência de alguns crimes, produzindo nas pessoas a sensação de que elas não estão sozinhas e indefesas diante da atuação dos criminosos e reforçando os laços de solidariedade e os mecanismos de coesão social. Mas, para isso, é necessário que elas gozem da confiança dos cidadãos. Sem esta confiança, as pessoas não estarão dispostas a cooperar com as investigações ou a ajudar os programas comunitários (Davis e Henderson, 2003; Markowkiz et al., 2001). Neste contexto, dentre os fatores mais impactantes no medo estão a confiança e a satisfação com os serviços de polícia. Alguns estudos sugerem que pessoas que confiam na polícia tendem a sentir menos medo (Bennett, 1991; Box et al., 1988; Handow et al., 2003; Scheider et al., 2003). 
No contexto da América Latina, vale a pena destacar uma pesquisa realizada por Dammert (2016) sobre a situação do Chile. Apesar da situação da incidência da violência e criminalidade ser baixa e apesar da polícia chilena (Carabineiros) ser a instituição pública mais bem avaliada pelos chilenos, o medo da população vem crescendo continuamente. Dessa situação, Dammert conclui que o medo do crime constitui um problema social autônomo em relação ao crime. Para explicar essa situação contraditória, na qual uma boa avaliação da polícia convive bem com um medo cada vez maior em relação ao crime, Dammert destaca que prevalece na população do Chile uma percepção de que a polícia está de mãos atadas porque não tem as funções e capacidades para atuar e a justiça libera a maior parte dos presos sem nenhum castigo. Por fim, Dammert traz ainda a constatação de que as pessoas de maior nível socioeconômico, justamente as menos vitimadas por crimes e, por conseguinte, as que menos buscam os serviços da polícia, são as que mais confiam na polícia. Por outro lado, dentre os menos privilegiados, que são de modo geral mais vitimados, temos uma confiança menor e, dentre estes, aqueles que buscam o serviço da polícia são os que possuem a menor confiança.

No Brasil, ainda são poucos os estudos que buscam entender a relação entre confiança na polícia e medo do crime. Oliveira Jr. e Alencar (2015) sugerem que uma percepção negativa tem efeito significativo sobre a tendência de optar-se por não procurar a polícia quando da ocorrência de um crime. A partir de uma amostra nacional, os autores verificaram que cerca de $28 \%$ das vítimas de roubos ou furtos não registraram o crime na polícia e outros $21 \%$ só procuram a polícia pela necessidade legal do boletim de ocorrência.

Oliveira Jr. (2011) avaliou a satisfação da população quanto ao desempenho das polícias. A partir de uma amostra nacional, o autor verificou que os entrevistados tendem a fazer uma avaliação negativa do trabalho policial. Entretanto, as pessoas que já acionaram a polícia avaliaram o atendimento de forma bem mais positiva. Entre as pessoas que já tiveram contato com a polícia, a razão de chance de se fazer uma boa avaliação do atendimento realizado por policiais diminui significativamente quando a cor do entrevistado não é branca. Ainda segundo o autor, a confiança nas instituições policiais é, em boa medida, explicada pela avaliação do desempenho das polícias, especialmente a avaliação difusa. $O$ fato de haver um contato anterior, cujo atendimento foi mal avaliado, tem efeito negativo significativo 
sobre a confiança. Ou seja, não somente a percepção geral do desempenho das instituições policiais influencia o grau de confiança, como também a percepção sobre o desempenho de policiais em situações específicas.

Há uma série de fatores que influenciam a imagem difusa que a população faz das polícias. Silva e Beato Filho (2013) apontam que a confiança na polícia está correlacionada à confiança na justiça. É provável que possa existir confusão entre as funções do trabalho policial e do sistema de justiça criminal. Os autores observaram também alta correlação entre a confiança na polícia e nos governos, especialmente federal e estadual, pois é impossível analisar a confiança na polícia em separado da confiança nos governos.

O desempenho da atuação da polícia é algo difícil de medir. É preciso diferenciar a confiança na polícia da satisfação com os serviços prestados por ela. Afinal de contas, é possível confiar nas polícias e não estar satisfeito com os seus serviços. Além disso, pode haver percepções distintas sobre a qualidade da atuação da polícia entre aqueles que tiveram contato com policiais e aqueles que não tiveram (Oliveira, 2011). A partir deste apanhado teórico e dos dados coletados pela Pesquisa Distrital de Vitimização estruturamos as seguintes hipóteses:

- Hipótese 1: A presença do policiamento nas vias públicas, especialmente a pé, reduz o medo do crime;

- Hipótese 2: Entrar em contato com a polícia diminui o medo do crime;

- Hipótese 3: Confiar na polícia reduz o medo do crime;

- Hipótese 4: Avaliar positivamente o serviço prestado pela polícia diminui o medo do crime;

- Hipótese 5: Avaliar positivamente a conduta dos policiais reduz o medo do crime e

- Hipótese 6: Saber ou Presenciar violência e corrupção policial aumenta o medo do crime. 


\section{METODOLOGIA}

A fonte de dados para elaboração deste artigo foi a Pesquisa de Vitimização Distrital realizada no Distrito Federal em 2015. Esta pesquisa envolveu a realização de um survey em uma amostra domiciliar de 19.537 moradores no Distrito Federal com idade acima de 16 anos. A pesquisa, representativa da situação do Distrito Federal e de cada uma das 31 Regiões Administrativas em particular, tem uma margem de erro de 0,7\% para o Distrito Federal.

O medo do crime é uma propriedade emocional e psicológica que varia de intensidade em cada pessoa. Ele pode estar relacionado aos sentimentos difusos de incerteza com a vida moderna, à percepção de desordem, às dificuldades da vida urbana, bem como à violência e à criminalidade (Hale, 1996). O medo do crime é uma combinação de tempo e percepção. Portanto, tem natureza efêmera e transitória e depende das representações sociais que fazemos dos riscos e perigos que nos cercam (Chaddee et al., 2016). Estas representações sociais variam de acordo com o perfil dos indivíduos, classe social e lugar onde residem, sua vitimização pela violência e criminalidade e suas relações com os órgãos públicos, especialmente as polícias. Ou seja, embora seja uma experiência individual, o medo do crime é socialmente construído.

Neste artigo, centramos nossa abordagem do medo na dimensão sensação de insegurança. Na Pesquisa Distrital de Vitimização, as pessoas foram questionadas sobre sua sensação de segurança nos seguintes contextos: (1) casa sozinho; (2) casa acompanhado pela família; (3) casa acompanhado apenas pelo cônjuge; (4) no bairro onde reside de dia; (5) no bairro onde reside à noite; (6) outros bairros da cidade de dia; e (7) outros bairros da cidade à noite.

Os dados da pesquisa de vitimização revelam que as situações de medo do crime são mais comuns em contexto noturno e em regiões desconhecidas (outros bairros da cidade). Por outro lado, as pessoas tendem a se sentir mais seguras em casa e no bairro onde residem, sobretudo durante o dia. Apenas 16,1\% da população não se sente insegura em nenhuma situação e, por outro lado, 13,3\% da população se sente insegura em todas as situações analisadas. 
Tabela 1

Medo do Crime por Situações ou Locais (\%)

\begin{tabular}{lcccc}
\hline Situações & \multicolumn{4}{c}{ Sensação de Segurança } \\
& $\begin{array}{c}\text { Muito } \\
\text { seguro }\end{array}$ & Seguro & Inseguro & $\begin{array}{c}\text { Muito } \\
\text { inseguro }\end{array}$ \\
\hline Casa acompanhado apenas pelo cônjuge & 15,2 & 68,4 & 14,1 & 2,3 \\
Casa acompanhado pelos familiares & 14,4 & 68,6 & 14,7 & 2,2 \\
Casa sozinho & 9,1 & 65,4 & 22,2 & 3,3 \\
Bairro onde reside durante o dia & 5,5 & 53,9 & 34,1 & 6,4 \\
Bairro onde reside durante a noite & 3,0 & 31,9 & 43,4 & 21,7 \\
Outros bairros durante o dia & 1,4 & 33,3 & 54,2 & 11,1 \\
Outros bairros durante a noite & 0,9 & 18,8 & 53,6 & 26,7 \\
\hline
\end{tabular}

Fonte: GDF/SSP - Pesquisa de Vitimização Distrital (2015).

A presença e qualidade do policiamento na vizinhança foram abordadas da seguinte forma: "Como o(a) Sr(a) avalia os seguintes serviços em sua vizinhança ou proximidades: (a) policiamento a pé; (b) policiamento em viatura ou moto". As possíveis respostas para esta questão eram: não existe; ótimo; bom; regular; ruim; péssimo.

O fato de ter presenciado a atuação da polícia foi abordado da seguinte forma: "Vou citar algumas ações da POLÍCIA MILITAR e gostaria de saber se, nos últimos 12 meses, o(a) Sr(a) PRESENCIOU alguma delas na sua vizinhança: (a) apreensão de armas, drogas ou contrabandos; (b) enfrentamento armado entre a polícia e o tráfico, gangues, facções criminosas e milícias; (c) revistas de veículos; (d) revistas pessoais; (e) perseguição policial; (f) atuação da polícia em crimes que estavam acontecendo e (g) pessoas sendo presas".

O fato de ter entrado em contato com a polícia foi abordado da seguinte forma: "Nos últimos 12 meses o(a) Sr(a) teve algum contato com a polícia para: (a) pedido de informação; (b) assistência ou socorro; (c) acidente de trânsito; (d) intervenção em crime em andamento; (e) comunicação de crime; (f) blitz e (g) revista pessoal".

A confiança nas polícias foi abordada da seguinte forma: "De uma maneira geral, em se tratando da Polícia Militar / Polícia Civil o(a) Senhor(a): (1) confia muito; (2) confia ou (3) não confia". 
A conduta dos policiais militares foi avaliada a partir das seguintes assertivas: (1) os Policiais Militares sabem como agir em situações de risco e perigo; (2) os Policiais Militares atendem as pessoas com cortesia, rapidez e segurança; (3) os Policiais Militares abordam suspeitos de forma segura e dentro da lei; (4) os Policiais Militares não estão preparados para usar armas de fogo; (5) os Policiais Militares abusam do uso da força e de sua autoridade; (6) os Policiais Militares fazem "vista grossa" à desonestidade de seus colegas; (7) os Policiais Militares são preconceituosos quando abordam as pessoas.

A qualidade dos serviços prestados pela Polícia Militar foi avaliada em relação aos seguintes itens: (1) rapidez e qualidade no atendimento emergencial; (2) abordagem policial em blitz, revista pessoal e (3) trabalho na organização e no ordenamento do trânsito. Já o atendimento realizado pela Polícia Civil foi avaliado em relação aos seguintes itens: (1) investigação de crimes; (2) rapidez e qualidade no atendimento e na elaboração dos documentos como registro de ocorrências, declarações e atestados.

Por fim, para analisar a percepção das pessoas sobre a violência praticada pela polícia na vizinhança, foi questionado aos entrevistados se "nos últimos 12 meses, pelo que o(a) Senhor(a) sabe na sua vizinhança existem: (1) policiais ameaçando ou agredindo pessoas e (2) pessoas recebendo dinheiro de pessoas".

Vale ressaltar que os itens abordados acima sobre a confiança e a avaliação da qualidade do serviço e da conduta dos policiais foram questionados aos entrevistados independentemente de eles terem ou não estabelecido contato efetivo com a polícia. Ou seja, estamos tratando de uma opinião pública sobre a atuação da polícia que existe na cabeça das pessoas independentemente de elas terem sido de fato clientes do serviço prestado pela polícia. Da mesma forma, ressaltamos que ter ficado sabendo da existência de violência policial na vizinhança não significa ter presenciado o ato violento. Assim como a definição sobre o que é ato violento é algo muito subjetivo, sendo que o mesmo ato pode ser encarado como violento por uma pessoa e não violento por outra. 


\section{PRESENÇA E QUALIDADE DO POLICIAMENTO E O MEDO DO CRIME}

No Distrito Federal, em 2015, 93,4\% dos entrevistados afirmaram que viram policiamento motorizado e $37 \%$ afirmaram que viram policiamento a pé na vizinhança. $\mathrm{O}$ policiamento em viatura ou moto é melhor avaliado no Distrito Federal do que o policiamento a pé. Em relação ao policiamento em viatura, 32\% consideram ótimo/bom e $28 \%$ consideram ruim/péssimo. Em relação ao policiamento a pé, 22\% consideram ótimo/bom e 49\% consideram ruim/péssimo.

A análise dos impactos destes fatores no medo dos indivíduos confirma nossa expectativa de que as pessoas que percebem a presença de policiamento nas vias públicas da vizinhança, especialmente a pé, sentem menos medo. $\mathrm{O}$ medo no bairro onde residem durante o dia está presente em $25 \%$ dos que consideraram o policiamento a pé na vizinhança como bom/ótimo e 32\% dos que consideraram o policiamento em viatura na vizinhança como bom/ótimo. Cabe salientar que, quanto melhor a avaliação do policiamento, independentemente de ser a pé ou em viatura, menor é o medo.

Tabela 2

Existe Policiamento na Vizinhança (\%)

\begin{tabular}{lcc}
\hline $\begin{array}{l}\text { Existe na Vizinhança } \\
\text { Policiamento }\end{array}$ & $\begin{array}{c}\text { Em Viatura ou } \\
\text { Moto }\end{array}$ & A Pé \\
\hline Não tem & 6,6 & 63,0 \\
Sim & 93,4 & 37,0 \\
\hline Total & 100,0 & 100,0 \\
\hline Fonte: GDF/SSP - Pesquisa de Vitimização Distrital (2015).
\end{tabular}

Tabela 3

Avaliação do Policiamento Segundo Tipo de Policiamento (\%)

\begin{tabular}{lcc}
\hline Avaliação do Policiamento & $\begin{array}{c}\text { Em Viatura ou } \\
\text { Moto }\end{array}$ & A Pé \\
\hline Ótimo/Bom & 32,3 & 21,8 \\
Regular & 39,1 & 29,2 \\
Ruim/Péssimo & 28,6 & 49,0 \\
\hline Total & 100,0 & 100,0 \\
\hline Fonte: GDF/SSP - Pesquisa de Vitimização Distrital (2015).
\end{tabular}

A análise da Tabela 4 nos permite concluir que o policiamento a pé tem impacto concentrado especialmente no medo das pessoas em casa e nas vias públicas do bairro onde elas residem, pois $25,3 \%$ das 
pessoas que avaliaram positivamente o policiamento a pé (ótimo/ bom) declararam sentir-se pouco seguros ou inseguros. O policiamento em viatura tem impacto sobre o medo menor que o do policiamento a pé. Ambas as modalidades de policiamento têm maior efeito sobre o medo do crime em casa e nas vias públicas do bairro onde as pessoas residem. A presença de policiamento, seja a pé ou em viatura, tem menor impacto sobre o medo do crime nas vias públicas dos outros bairros da cidade.

Tabela 4

Medo do Crime e Presença e Qualidade do Policiamento na Vizinhança (\%)

\begin{tabular}{|c|c|c|c|c|c|c|c|c|c|c|}
\hline \multirow[b]{2}{*}{ Categorias } & \multicolumn{5}{|c|}{ Policiamento a Pé } & \multicolumn{5}{|c|}{ Policiamento em Viatura } \\
\hline & $\begin{array}{l}\text { Ótimo/ } \\
\text { Bom }\end{array}$ & Regular & $\begin{array}{l}\text { Ruim/ } \\
\text { Péssimo }\end{array}$ & $\begin{array}{l}\text { Não } \\
\text { Existe }\end{array}$ & $\begin{array}{c}\text { Dif } \\
\text { Ótimo } \\
\text { /Não } \\
\text { Existe }\end{array}$ & $\begin{array}{l}\text { Ótimo/ } \\
\text { Bom }\end{array}$ & Regular & $\begin{array}{l}\text { Ruim/ } \\
\text { Péssimo }\end{array}$ & $\begin{array}{l}\text { Não } \\
\text { Existe }\end{array}$ & $\begin{array}{c}\text { Dif } \\
\text { Ótimo } \\
\text { / Não } \\
\text { Existe }\end{array}$ \\
\hline $\begin{array}{l}\text { Bairro onde reside } \\
\text { durante o dia }\end{array}$ & 25,3 & 35,4 & 38,5 & 44,2 & 42,8 & 31,6 & 42,0 & 47,8 & 44,8 & 29,5 \\
\hline $\begin{array}{l}\text { Bairro onde reside } \\
\text { durante a noite }\end{array}$ & 47,1 & 56,8 & 65,7 & 68,9 & 31,6 & 57,6 & 67,1 & 71,1 & 64,7 & 11,0 \\
\hline $\begin{array}{l}\text { Outros bairros } \\
\text { durante o dia }\end{array}$ & 50,4 & 62,5 & 64,1 & 68,3 & 26,2 & 58,0 & 66,8 & 70,4 & 70,4 & 17,6 \\
\hline $\begin{array}{l}\text { Outros bairros } \\
\text { durante a noite }\end{array}$ & 68,0 & 75,4 & 81,9 & 82,5 & 17,6 & 76,7 & 82,4 & 81,2 & 82,0 & 6,5 \\
\hline Casa sozinho & 15,6 & 20,8 & 24,6 & 27,9 & 44,1 & 18,3 & 25,3 & 33,3 & 27,4 & 33,2 \\
\hline $\begin{array}{l}\text { Casa acompanhado } \\
\text { pelos familiares }\end{array}$ & 8,9 & 13,1 & 17,6 & 18,6 & 52,2 & 10,4 & 16,8 & 23,9 & 19,9 & 47,7 \\
\hline $\begin{array}{l}\text { Casa acompanhado } \\
\text { só do cônjuge }\end{array}$ & 8,2 & 11,9 & 16,5 & 18,4 & 55,4 & 10,2 & 16,5 & 22,6 & 19,7 & 48,2 \\
\hline
\end{tabular}

Fonte: GDF/SSP - Pesquisa de Vitimização Distrital (2015).

\section{A ATUAÇÃO DA POLÍCIA E O MEDO DO CRIME}

Parte significativa da população do Distrito Federal viu a Polícia Militar executando alguma atividade na sua vizinhança, em 2016, sendo que $19 \%$ viram a polícia atuando em operações de apreensão de armas ou drogas, $32 \%$ viram a polícia revistando veículos, $49 \%$ viram a polícia revistando pessoas e $32 \%$ viram pessoas sendo presas.

O medo é maior entre aqueles que presenciaram a polícia executando alguma atividade do que entre aqueles que não presenciaram. Assim, por exemplo, o medo no bairro onde reside durante o dia está presente entre $36 \%$ dos que não presenciaram nenhuma ação da polícia e $44 \%$ dos que presenciaram. Cabe lembrar que em nosso apanhado 
teórico percebemos que alguns pesquisadores apontavam uma relação direta entre estes fenômenos e outros apontavam uma relação inversa.

Tabela 5

Presenciou Atuação da Polícia Militar na Vizinhanças nos Últimos 12 Meses (\%)

\begin{tabular}{lccc}
\hline Atividades & Sim & Não & TOTAL \\
\hline Apreensão de armas, drogas etc. & 18,7 & 81,3 & 100,0 \\
Enfrentamento armado entre a polícia e o tráfico, gangues, facções & 9,0 & 91,0 & 100,0 \\
Revistas de veículos & 32,1 & 67,9 & 100,0 \\
Revistas pessoais & 48,9 & 51,1 & 100,0 \\
Perseguição policial & 18,9 & 81,1 & 100,0 \\
Atuação da polícia em crimes que estavam acontecendo & 15,2 & 84,8 & 100,0 \\
Pessoas sendo presas & 32,3 & 67,7 & 100,0 \\
\hline
\end{tabular}

Fonte: GDF/SSP - Pesquisa de Vitimização Distrital (2015).

Tabela 6

Medo do Crime e Percepção da Atuação da PM na Vizinhança (\%)

\begin{tabular}{llll}
\hline \multirow{2}{*}{ Categorias } & \multicolumn{3}{c}{ Presenciou Atuação da PM } \\
\cline { 2 - 4 } & Não & Sim & Dif \\
\hline Bairro onde reside durante o dia & 36,2 & 43,9 & $-7,7$ \\
Bairro onde reside durante a noite & 60,1 & 68,8 & $-8,7$ \\
Outros bairros durante o dia & 62,4 & 67,4 & $-5,0$ \\
Outros bairros durante a noite & 76,9 & 82,8 & $-5,9$ \\
Casa sozinho & 23,4 & 27,0 & $-3,6$ \\
Casa acompanhado familiares & 16,0 & 17,7 & $-1,7$ \\
Casa acompanhado apenas pelo cônjuge & 15,1 & 17,5 & $-2,4$ \\
\hline
\end{tabular}

Fonte: GDF/SSP - Pesquisa de Vitimização Distrital (2015).

\section{CONTATO COM A POLÍCIA E O MEDO DO CRIME}

Estabelecer um contato direto com a polícia é menos frequente do que presenciar a polícia atuando. O motivo mais frequente do contato foi para pedido de informações $(8,8 \%)$, seguido de comunicação de crime $(7,2 \%)$, em função de blitz $(5,3 \%)$, para solicitar assistência ou primeiros socorros $(4,4 \%)$ e no caso de acidentes de trânsito $(3,1 \%)$.

Dentre aqueles que estabeleceram contato, percebemos um aumento da sensação de insegurança, sendo o maior impacto do medo no bairro onde a pessoa reside. Assim, o medo nas vias públicas do bairro 
onde a pessoa reside está presente em $45 \%$ dos que estabeleceram contato com a polícia e 39\% dos que não estabeleceram contato.

Tabela 7

Estabeleceu Contato com a Polícia nos Últimos 12 Meses por Tipo de Contato (\%)

\begin{tabular}{lccc}
\hline \multirow{2}{*}{ Tipo de Contato com a Polícia } & \multicolumn{3}{c}{ Ocorreu Contato } \\
\cline { 2 - 4 } & Sim & Não & Total \\
\hline Pedido de informação & 8,8 & 91,2 & 100,0 \\
Assistência ou primeiros socorros & 4,4 & 95,6 & 100,0 \\
Acidente de trânsito & 3,1 & 96,9 & 100,0 \\
Intervenção em crime em andamento & 2,8 & 97,2 & 100,0 \\
Comunicação de crime & 7,2 & 92,8 & 100,0 \\
Blitz & 5,3 & 94,7 & 100,0 \\
Revista pessoal & 2,8 & 97,2 & 100,0 \\
\hline
\end{tabular}

Fonte: GDF/SSP - Pesquisa de Vitimização Distrital (2015).

Tabela 8

Medo do Crime e Contato Estabelecido com a Polícia (\%)

\begin{tabular}{llll}
\hline \multirow{2}{*}{ Categorias } & \multicolumn{3}{c}{ Ocorreu Contato com a Polícia } \\
\cline { 2 - 4 } & Não & Sim & Dif \\
\hline Bairro onde reside durante o dia & 39,3 & 45,0 & $-5,7$ \\
Bairro onde reside durante a noite & 63,9 & 69,0 & $-5,1$ \\
Outros bairros durante o dia & 64,8 & 66,8 & $-2,0$ \\
Outros bairros durante a noite & 79,4 & 83,4 & $-4,0$ \\
Casa sozinho & 25,3 & 25,9 &,- 6 \\
Casa acompanhado pelos familiares & 16,9 & 17,1 &,- 2 \\
Casa acompanhado apenas pelo cônjuge & 16,4 & 16,8 &,- 4 \\
\hline
\end{tabular}

Fonte: GDF/SSP - Pesquisa de Vitimização Distrital (2015).

\section{CONFIANÇA NA POLÍCIA E O MEDO DO CRIME}

A confiança da população do Distrito Federal tanto na Polícia Militar quanto na Polícia Civil é elevada. Mais de $82 \%$ dos entrevistados declaram confiar na Polícia Militar e 87\% disseram confiar na Polícia Civil. Apenas 17,8\% da população não confia na Polícia Militar e 12,7\% não confia na Polícia Civil.

Tabela 9

Confiança na Polícia Militar e na Polícia Civil (\%)

\begin{tabular}{lcccc}
\hline Instituição & Confia Muito & Confia & Não Confia & Total \\
\hline Polícia Militar & 24,4 & 57,7 & 17,8 & 100,0 \\
Polícia Civil & 28,0 & 59,4 & 12,7 & 100,0 \\
\hline
\end{tabular}

Fonte: GDF/SSP - Pesquisa de Vitimização Distrital (2015). 
O impacto da confiança da população na polícia mostrou ser significativo em relação ao medo do crime. Assim, percebemos que, em relação ao medo no bairro onde reside durante o dia, dentre os que confiam muito na $\mathrm{PM}, 31 \%$ se sentem inseguros e, dentre os que não confiam, $50 \%$ se sentem inseguros. Outro ponto a ser salientado é que o impacto da confiança na Polícia Militar é maior do que o impacto da confiança na Polícia Civil. A confiança na polícia exerce um impacto maior no medo quando a pessoa está no bairro onde reside, seja de dia ou de noite. Por outro lado, seu impacto é menor quando a pessoa está em casa acompanhada ou está em outro bairro distinto daquele onde ela reside à noite.

Tabela 10

Medo do Crime e Confiança na PMDF e PCDF (\%)

\begin{tabular}{|c|c|c|c|c|c|c|c|c|}
\hline \multirow[b]{2}{*}{ Categorias } & \multicolumn{4}{|c|}{ Confiança na Polícia Militar } & \multicolumn{4}{|c|}{ Confiança na Polícia Civil } \\
\hline & 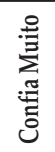 & 节 & 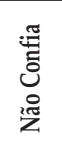 & 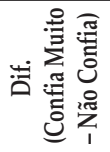 & 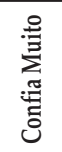 & है & 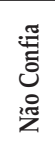 & 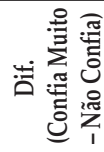 \\
\hline $\begin{array}{l}\text { Bairro onde reside } \\
\text { durante o dia }\end{array}$ & 30,5 & 42,0 & 49,9 & $-19,4$ & 32,5 & 42,4 & 49,6 & $-17,1$ \\
\hline $\begin{array}{l}\text { Bairro onde reside } \\
\text { durante a noite }\end{array}$ & 55,8 & 66,9 & 71,9 & $-16,1$ & 58,0 & 67,1 & 71,1 & $-13,1$ \\
\hline $\begin{array}{l}\text { Outros bairros } \\
\text { durante o dia }\end{array}$ & 57,9 & 66,7 & 70,8 & $-12,9$ & 59,5 & 66,7 & 71,3 & $-11,8$ \\
\hline $\begin{array}{l}\text { Outros bairros } \\
\text { durante a noite }\end{array}$ & 76,0 & 81,4 & 82,7 & $-6,7$ & 77,0 & 81,4 & 82,8 & $-5,8$ \\
\hline Casa sozinho & 18,9 & 26,1 & 32,6 & $-13,7$ & 20,0 & 26,4 & 33,3 & $-13,3$ \\
\hline $\begin{array}{l}\text { Casa acompanhado } \\
\text { pelos familiares }\end{array}$ & 12,4 & 17,0 & 23,3 & $-10,9$ & 13,4 & 17,4 & 23,0 & $-9,6$ \\
\hline $\begin{array}{l}\text { Casa acompanhado } \\
\text { apenas pelo cônjuge }\end{array}$ & 12,6 & 16,4 & 22,0 & $-9,4$ & 13,7 & 16,5 & 22,3 & $-8,6$ \\
\hline
\end{tabular}

Fonte: GDF/SSP - Pesquisa de Vitimização Distrital (2015).

\section{AVALIAÇÃO DO SERVIÇO PRESTADO PELA POLÍCIA E O MEDO DO CRIME}

A população do Distrito Federal avalia de modo positivo a maior parte das atividades executadas pelas polícias militar e civil. Cabe destacar que, em relação à Polícia Civil, 59\% deram a classificação ótimo/bom à investigação de crimes; em relação à Polícia Militar, $58 \%$ deram a classificação ótimo/bom a abordagens em blitz e revistas pessoais. 
De forma geral, aqueles que avaliam positivamente tanto os serviços da Polícia Militar do Distrito Federal (PMDF) quanto os serviços da Polícia Civil do Distrito Federal (PCDF) tendem a ter menos medo do que os que estão insatisfeitos. As duas atividades mais impactantes na determinação do medo foram, no âmbito da Polícia Militar, a rapidez e qualidade do atendimento emergencial e, no âmbito da Polícia Civil, a qualidade da investigação dos crimes. As duas atividades menos impactantes foram a abordagem da Polícia Militar em blitz e revistas pessoais e o serviço de elaboração de documentos pela Polícia Civil (nada consta e registro de ocorrências).

O impacto da qualidade do serviço prestado é mais forte fora do ambiente doméstico, especialmente durante o dia e no bairro onde a pessoa reside. Por outro lado, o impacto da qualidade do serviço é muito pequeno no ambiente doméstico, especialmente quando a pessoa está acompanhada em casa.

Tabela 11

Avaliação da Qualidade do Serviço Prestado pela Polícia Militar e Polícia Civil (\%)

\begin{tabular}{|c|c|c|c|c|c|}
\hline Instituição & Contato & $\begin{array}{l}\text { Ótimol } \\
\text { Bom }\end{array}$ & Regular & $\begin{array}{l}\text { Ruim/ } \\
\text { Péssimo }\end{array}$ & Total \\
\hline \multirow{3}{*}{$\begin{array}{l}\text { Polícia } \\
\text { Militar }\end{array}$} & $\begin{array}{l}\text { Rapidez e qualidade no } \\
\text { atendimento emergencial }\end{array}$ & 45,0 & 35,0 & 20,0 & 100,0 \\
\hline & $\begin{array}{l}\text { Abordagem policial em blitz e } \\
\text { Revistas pessoais }\end{array}$ & 58,3 & 31,8 & 9,8 & 100,0 \\
\hline & $\begin{array}{l}\text { Trabalho na organização e } \\
\text { ordenamento do trânsito }\end{array}$ & 56,7 & 33,2 & 10,1 & 100,0 \\
\hline \multirow[b]{2}{*}{ Polícia Civil } & Investigação dos crimes & 59,1 & 29,1 & 11,7 & 100,0 \\
\hline & $\begin{array}{l}\text { Rapidez e qualidade no } \\
\text { atendimento e na elaboração dos } \\
\text { documentos como registro de } \\
\text { ocorrências e nada consta }\end{array}$ & 57,8 & 29,9 & 12,3 & 100,0 \\
\hline
\end{tabular}


Tabela 12

Medo do Crime e Qualidade do Serviço Prestado pela PMDF (\%)

\begin{tabular}{|c|c|c|c|c|c|c|c|c|c|c|c|c|}
\hline \multirow[b]{2}{*}{ Categorias } & \multicolumn{4}{|c|}{$\begin{array}{l}\text { Rapidez e Qualidade no } \\
\text { Atendimento Emergencial }\end{array}$} & \multicolumn{8}{|c|}{$\begin{array}{c}\text { Abordagem policial em Blitz Trabalho na Organização e } \\
\text { e Revistas Pessoais } \quad \text { Ordenamento do Trânsito }\end{array}$} \\
\hline & 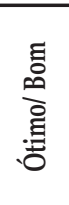 & పే & 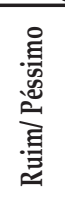 & 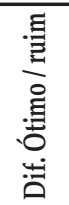 & 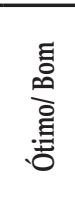 & 禀 & 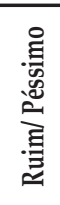 & 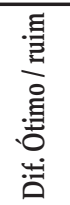 & 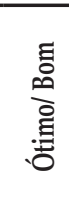 & 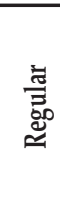 & 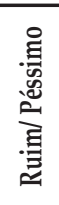 & 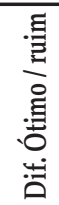 \\
\hline $\begin{array}{l}\text { Bairro onde } \\
\text { reside durante } \\
\text { o dia }\end{array}$ & 35,6 & 41,9 & 51,4 & $-15,8$ & 37,5 & 42,1 & 47,9 & $-10,4$ & 36,9 & 42,6 & 49,3 & $-12,4$ \\
\hline $\begin{array}{l}\text { Bairro onde } \\
\text { reside durante } \\
\text { a noite }\end{array}$ & 59,4 & 67,2 & 74,8 & $-15,4$ & 61,9 & 66,4 & 69,6 & $-7,7$ & 61,8 & 67,4 & 71,9 & $-10,1$ \\
\hline $\begin{array}{l}\text { Outros bairros } \\
\text { durante o dia }\end{array}$ & 60,6 & 66,8 & 74,0 & $-13,4$ & 61,7 & 67,4 & 72,6 & $-10,9$ & 61,6 & 67,9 & 74,4 & $-12,8$ \\
\hline $\begin{array}{l}\text { Outros bairros } \\
\text { durante a noite }\end{array}$ & 76,2 & 82,1 & 86,5 & $-10,3$ & 78,0 & 81,4 & 83,0 & $-5,0$ & 78,0 & 82,4 & 85,2 & $-7,2$ \\
\hline Casa sozinho & 23,6 & 25,7 & 31,3 & $-7,7$ & 23,4 & 26,5 & 31,0 & $-7,6$ & 22,9 & 27,3 & 31,7 & $-8,8$ \\
\hline $\begin{array}{l}\text { Casa } \\
\text { acompanhado } \\
\text { pelos familiares }\end{array}$ & 16,0 & 16,8 & 21,2 & $-5,2$ & 15,5 & 18,4 & 22,5 & $-7,0$ & 15,2 & 18,9 & 21,7 & $-6,5$ \\
\hline $\begin{array}{l}\text { Casa } \\
\text { acompanhado } \\
\text { pelo cônjuge }\end{array}$ & 15,8 & 16,3 & 20,5 & $-4,7$ & 15,2 & 17,8 & 21,3 & $-6,1$ & 14,6 & 18,4 & 22,0 & $-7,4$ \\
\hline
\end{tabular}

Tabela 13

Medo do Crime e Qualidade do Serviço Prestado pela PCDF (\%)

\begin{tabular}{|c|c|c|c|c|c|c|c|c|}
\hline \multirow{2}{*}{ Categorias } & \multicolumn{4}{|c|}{ Investigação do Crimes } & \multicolumn{4}{|c|}{$\begin{array}{l}\text { Rapidez e qualidade na elaboração } \\
\text { documentos }\end{array}$} \\
\hline & $\begin{array}{c}\text { Ótimol } \\
\text { Bom }\end{array}$ & Regular & $\begin{array}{l}\text { Ruim/ } \\
\text { Péssimo }\end{array}$ & $\begin{array}{l}\text { Dif. Ótimo } \\
\text { /Ruim }\end{array}$ & $\begin{array}{c}\text { Ótimol } \\
\text { Bom }\end{array}$ & Regular & $\begin{array}{l}\text { Ruim/ } \\
\text { Péssimo }\end{array}$ & $\begin{array}{l}\text { Dif. Ótimo } \\
\text { / Ruim }\end{array}$ \\
\hline $\begin{array}{l}\text { Bairro onde reside } \\
\text { durante o dia }\end{array}$ & 36,9 & 43,9 & 50,9 & $-14,0$ & 37,5 & 43,3 & 47,7 & $-10,2$ \\
\hline $\begin{array}{l}\text { Bairro onde reside } \\
\text { durante a noite }\end{array}$ & 62,1 & 68,3 & 71,4 & $-9,3$ & 62,5 & 67,2 & 70,1 & $-7,6$ \\
\hline $\begin{array}{l}\text { Outros bairros } \\
\text { durante o dia }\end{array}$ & 61,8 & 68,6 & 74,4 & $-12,6$ & 61,9 & 67,9 & 71,6 & $-9,7$ \\
\hline $\begin{array}{l}\text { Outros bairros } \\
\text { durante a noite }\end{array}$ & 77,4 & 83,7 & 85,1 & $-7,7$ & 77,7 & 82,7 & 84,6 & $-6,9$ \\
\hline Casa sozinho & 23,8 & 26,8 & 31,0 & $-7,2$ & 23,9 & 26,6 & 30,6 & $-6,7$ \\
\hline $\begin{array}{l}\text { Casa acompanhado } \\
\text { pelos familiares }\end{array}$ & 15,8 & 17,9 & 21,3 & $-5,5$ & 16,1 & 17,5 & 19,8 & $-3,7$ \\
\hline $\begin{array}{l}\text { Casa acompanhado } \\
\text { apenas pelo } \\
\text { cônjuge }\end{array}$ & 15,6 & 16,7 & 21,0 & $-5,4$ & 15,6 & 16,7 & 19,7 & $-4,1$ \\
\hline
\end{tabular}




\section{AVALIAÇÃO DA CONDUTA DOS POLICIAIS E O MEDO DO CRIME}

A população do Distrito Federal, de forma geral, avalia positivamente a conduta dos policiais militares. A maior parte dos entrevistados concordou com as seguintes afirmativas: sabem como agir em situações de risco e perigo (65\%), atendem as pessoas com cortesia, rapidez e segurança ( $52 \%$ ) e abordam suspeitos de forma segura e dentro da lei (56\%). Por outro lado, uma pequena parte dos entrevistados concorda com as afirmativas de que os policiais militares não estão preparados para usar armas de fogo (48\%), fazem "vista grossa" à desonestidade de seus colegas (37\%) e são preconceituosos quando abordam as pessoas na rua $(40 \%)$.

A análise da relação entre o medo e a avaliação da conduta dos policiais militares pela população evidenciou que as pessoas que concordam que os policiais sabem agir em situação de risco e perigo, atendem pessoas com cortesia, rapidez e segurança e abordam suspeitos de forma segura e dentro da lei são as que menos têm medo. No entanto, identificamos também que aqueles que concordam que os policiais abusam do uso da força e autoridade, fazem vista grossa à desonestidade dos colegas e são preconceituosos quando abordam as pessoas nas ruas são também as que menos têm medo. Apenas o argumento de que os policiais militares não estão preparados para usar armas de fogo teve um resultado neutro no sentido de que nem concordar e nem discordar desta afirmativa produz sensação de insegurança. Identificamos também que a qualidade da conduta dos policiais tem impacto maior nas situações envolvendo o trânsito das pessoas nas vias públicas fora do ambiente doméstico.

Tabela 14

Avaliação da Conduta dos Policiais Militares (\%)

\begin{tabular}{lcccc}
\hline Avaliação Conduta Policiais Militares & Concorda & Não Sabe & Discorda & Total \\
\hline Sabem como agir em situações de risco e perigo & 65,0 & 18,7 & 16,3 & 100,0 \\
Atendem as pessoas com cortesia, rapidez e segurança & 51,5 & 22,9 & 25,6 & 100,0 \\
Abordam suspeitos de forma segura e dentro da lei & 55,8 & 22,8 & 21,4 & 100,0 \\
Não estão preparados para usar armas de fogo & 47,9 & 22,9 & 29,2 & 100,0 \\
Abusam do uso da força e de sua autoridade & 35,1 & 23,5 & 41,5 & 100,0 \\
Fazem “vista grossa” à desonestidade de seus colegas & 36,8 & 26,6 & 36,6 & 100,0 \\
São preconceituosos quando abordam as pessoas na rua & 39,6 & 24,9 & 35,6 & 100,0 \\
\hline
\end{tabular}

Fonte: GDF/SSP - Pesquisa de Vitimização Distrital (2015). 
Tabela 15

Medo do Crime e Avaliação da Conduta dos Policiais Militares I (\%)

\begin{tabular}{|c|c|c|c|c|c|c|c|c|c|c|c|c|}
\hline \multirow[b]{2}{*}{ Categorias } & \multicolumn{4}{|c|}{$\begin{array}{c}\text { Sabem Agir em Situação } \\
\text { de Risco e Perigo }\end{array}$} & \multicolumn{4}{|c|}{$\begin{array}{c}\text { Atendem as Pessoas } \\
\text { com Cortesia, Rapidez e } \\
\text { Segurança }\end{array}$} & \multicolumn{4}{|c|}{$\begin{array}{c}\text { Abordam Suspeitos de } \\
\text { Forma Segura e dentro } \\
\text { da Lei }\end{array}$} \\
\hline & 胥 & 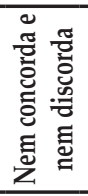 & 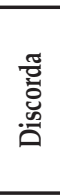 & 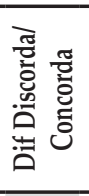 & 胥 & 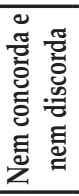 & 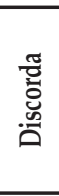 & 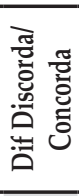 & 胥 & 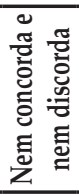 & 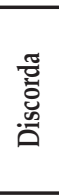 & 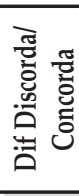 \\
\hline $\begin{array}{l}\text { Bairro onde reside } \\
\text { durante o dia }\end{array}$ & 38,1 & 43,2 & 47,1 & 9,0 & 35,7 & 42,1 & 48,8 & 13,1 & 37,5 & 41,1 & 47,7 & 10,2 \\
\hline $\begin{array}{l}\text { Bairro onde reside } \\
\text { durante a noite }\end{array}$ & 62,6 & 68,7 & 70,3 & 7,7 & 59,7 & 68,5 & 72,4 & 12,7 & 61,7 & 68,3 & 70,0 & 8,3 \\
\hline $\begin{array}{l}\text { Outros bairros } \\
\text { durante o dia }\end{array}$ & 63,0 & 68,0 & 71,4 & 8,4 & 61,9 & 66,2 & 71,3 & 9,4 & 62,9 & 65,4 & 70,5 & 7,6 \\
\hline $\begin{array}{l}\text { Outros bairros } \\
\text { durante a noite }\end{array}$ & 79,1 & 83,2 & 82,6 & 3,5 & 77,4 & 82,8 & 84,3 & 6,9 & 78,2 & 83,2 & 82,8 & 4,6 \\
\hline Casa sozinho & 24,9 & 25,5 & 28,2 & 3,3 & 23,9 & 25,6 & 29,4 & 5,5 & 24,5 & 24,1 & 30,1 & 5,6 \\
\hline $\begin{array}{l}\text { Casa acompanhado } \\
\text { pelos familiares }\end{array}$ & 16,6 & 16,6 & 19,2 & 2,6 & 16,3 & 15,9 & 20,1 & 3,8 & 16,8 & 14,2 & 20,9 & 4,1 \\
\hline $\begin{array}{l}\text { Casa acompanhado } \\
\text { pelo cônjuge }\end{array}$ & 16,1 & 16,0 & 18,6 & 2,5 & 15,9 & 15,5 & 19,4 & 3,5 & 16,6 & 13,3 & 20,2 & 3,6 \\
\hline
\end{tabular}

Tabela 16

Medo do Crime e Avaliação da Conduta dos Policiais Militares II (\%)

\begin{tabular}{|c|c|c|c|c|c|c|c|c|}
\hline \multirow[b]{2}{*}{ Categorias } & \multicolumn{4}{|c|}{$\begin{array}{c}\text { Não estão Preparados para usar } \\
\text { Armas de Fogo }\end{array}$} & \multicolumn{4}{|c|}{ Abusam do Uso da Força e Autoridade } \\
\hline & 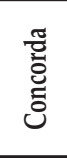 & 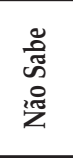 & 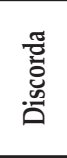 & 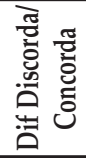 & 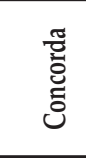 & 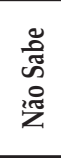 & 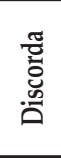 & 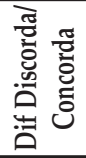 \\
\hline $\begin{array}{l}\text { Bairro onde reside } \\
\text { durante o dia }\end{array}$ & 38,9 & 41,7 & 41,6 & 2,7 & 35,4 & 39,4 & 45,3 & 9,9 \\
\hline $\begin{array}{l}\text { Bairro onde reside } \\
\text { durante a noite }\end{array}$ & 63,3 & 66,5 & 66,1 & 2,8 & 58,9 & 65,8 & 69,8 & 10,9 \\
\hline $\begin{array}{l}\text { Outros bairros } \\
\text { durante o dia }\end{array}$ & 64,6 & 65,8 & 65,3 & 0,7 & 61,8 & 63,4 & 69,1 & 7,3 \\
\hline $\begin{array}{l}\text { Outros bairros } \\
\text { durante a noite }\end{array}$ & 80,3 & 81,7 & 79,2 & $-1,1$ & 77,0 & 81,3 & 82,6 & 5,6 \\
\hline Casa sozinho & 25,3 & 24,1 & 27,2 & 1,9 & 22,7 & 22,6 & 29,7 & 7,0 \\
\hline $\begin{array}{l}\text { Casa acompanhado } \\
\text { pelos familiares }\end{array}$ & 17,4 & 15,1 & 18,1 &, 7 & 15,5 & 15,3 & 19,4 & 3,9 \\
\hline $\begin{array}{l}\text { Casa acompanhado } \\
\text { apenas pelo cônjuge }\end{array}$ & 17,4 & 14,4 & 17,2 &,- 2 & 15,4 & 14,1 & 19,1 & 3,7 \\
\hline
\end{tabular}

Fonte: GDF/SSP - Pesquisa de Vitimização Distrital (2015). 
Tabela 17

Medo do Crime e Avaliação da Conduta Policiais Militares III (\%)

\begin{tabular}{|c|c|c|c|c|c|c|c|c|}
\hline \multirow[b]{2}{*}{ Categorias } & \multicolumn{4}{|c|}{$\begin{array}{l}\text { Fazem Vista Grossa à Desonestidade } \\
\text { dos Colegas }\end{array}$} & \multicolumn{4}{|c|}{$\begin{array}{c}\text { São Preconceituosos Quando Abordam } \\
\text { as Pessoas nas Ruas }\end{array}$} \\
\hline & 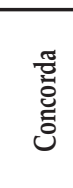 & 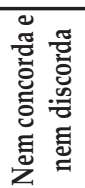 & 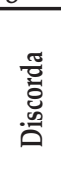 & 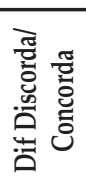 & 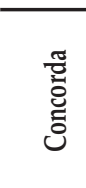 & 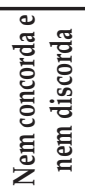 & 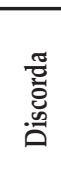 & 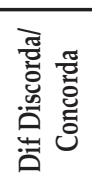 \\
\hline $\begin{array}{l}\text { Bairro onde reside } \\
\text { durante o dia }\end{array}$ & 38,1 & 39,9 & 44,1 & 6,0 & 36,1 & 39,4 & 46,2 & 10,1 \\
\hline $\begin{array}{l}\text { Bairro onde reside } \\
\text { durante a noite }\end{array}$ & 60,2 & 66,9 & 69,0 & 8,8 & 59,4 & 66,5 & 69,6 & 10,2 \\
\hline $\begin{array}{l}\text { Outros bairros } \\
\text { durante o dia }\end{array}$ & 63,5 & 62,4 & 68,0 & 4,5 & 62,2 & 60,9 & 71,2 & 9,0 \\
\hline $\begin{array}{l}\text { Outros bairros } \\
\text { durante a noite }\end{array}$ & 76,6 & 81,1 & 82,1 & 5,5 & 77,5 & 80,0 & 83,4 & 5,9 \\
\hline Casa sozinho & 24,4 & 22,6 & 29,5 & 5,1 & 23,5 & 22,3 & 30,1 & 6,6 \\
\hline $\begin{array}{l}\text { Casa acompanhado } \\
\text { pelos familiares }\end{array}$ & 16,6 & 15,0 & 19,9 & 3,3 & 16,1 & 14,7 & 20,2 & 4,1 \\
\hline $\begin{array}{l}\text { Casa acompanhado } \\
\text { apenas pelo cônjuge }\end{array}$ & 16,5 & 14,0 & 19,6 & 3,1 & 15,8 & 13,3 & 20,4 & 4,6 \\
\hline
\end{tabular}

Fonte: GDF/SSP - Pesquisa de Vitimização Distrital (2015).

\section{VIOLÊNCIA POLICIAL E O MEDO DO CRIME}

Em 2015, no Distrito Federal, 7,7\% da população ficou sabendo de policiais ameaçando pessoas. Outros $2,6 \%$ teve conhecimento de policiais extorquindo e $7,2 \%$ ficou sabendo de policiais agredindo pessoas. Cabe salientar que estamos tratando do ato de "ficar sabendo" e não de ter sido vítima da violência.

Tabela 18

Percepção da Existência de Violência Policial na Vizinhança (\%)

\begin{tabular}{lccc}
\hline Violência Policial na Vizinhança & Sim & Não & Total \\
\hline Policiais ameaçando pessoas & 7,7 & 92,3 & 100,0 \\
Policiais recebendo dinheiro de pessoas & 2,6 & 97,4 & 100,0 \\
Policiais agredindo pessoas & 7,2 & 92,8 & 100,0 \\
\hline
\end{tabular}

Fonte: GDF/SSP - Pesquisa de Vitimização Distrital (2015).

Conforme esperado, a presença da violência policial na vizinhança aumenta o medo do crime. Assim, no tocante ao bairro onde reside durante o dia, em relação à presença da violência policial, dentre os que ficaram sabendo, $48 \%$ se sentem inseguros e, dentre os que não 
ficaram sabendo, $40 \%$ se sentem inseguros. Dentre os que ficaram sabendo de policiais agredindo ou ameaçando pessoas, $47 \%$ se sentem inseguros e, dentre os que não ficaram sabendo, $40 \%$ se sentem inseguros. Por fim, dentre aqueles que ficaram sabendo de policiais extorquindo, $50 \%$ se sentem inseguros e, dentre os que não ficaram sabendo, $40 \%$ se sentem inseguros.

Tabela 19

Medo do Crime e Violência Policial na Vizinhança (\%)

\begin{tabular}{lccccccccc}
\hline \multirow{2}{*}{ Categorias } & \multicolumn{3}{c}{$\begin{array}{c}\text { Violência Policial na } \\
\text { Vizinhança }\end{array}$} & \multicolumn{3}{c}{ Ameaça e Agressão } & \multicolumn{3}{c}{ Extorsão } \\
\cline { 2 - 9 } & Não & Sim & Dif & Não & Sim & Dif & Não & Sim & Dif \\
\hline $\begin{array}{l}\text { Bairro onde reside } \\
\text { durante o dia }\end{array}$ & 39,8 & 48,0 & $-8,2$ & 39,9 & 46,9 & $-7,0$ & 40,1 & 49,6 & $-9,5$ \\
$\begin{array}{l}\text { Bairro onde reside } \\
\text { durante a noite }\end{array}$ & 64,7 & 66,7 & $-2,0$ & 64,8 & 66,7 & $-1,9$ & 64,8 & 66,2 & $-1,4$ \\
$\begin{array}{l}\text { Outros bairros } \\
\text { durante o dia }\end{array}$ & 65,1 & 67,7 & $-2,6$ & 65,2 & 66,3 & $-1,1$ & 65,3 & 66,3 & $-1,0$ \\
$\begin{array}{l}\text { Outros bairros } \\
\text { durante a noite }\end{array}$ & 80,2 & 77,6 & 2,6 & 80,2 & 77,2 & 3,0 & 80,1 & 74,9 & 5,2 \\
Casa sozinho & 25,3 & 30,3 & $-5,0$ & 25,4 & 28,3 & $-2,9$ & 25,3 & 36,2 & $-10,9$ \\
$\begin{array}{l}\text { Casa acompanhado } \\
\text { familiares }\end{array}$ & 16,7 & 22,7 & $-6,0$ & 16,9 & 20,5 & $-3,6$ & 16,8 & 29,5 & $-12,7$ \\
$\begin{array}{l}\text { Casa acompanhado } \\
\text { apenas pelo cônjuge }\end{array}$ & 16,1 & 23,3 & $-7,2$ & 16,3 & 21,5 & $-5,2$ & 16,3 & 29,3 & $-13,0$ \\
\hline Fonte: GDF/SSP - Pesquisa de Vitimização Distrital (2015). & & & & &
\end{tabular}

\section{ATUAÇÃO DA POLÍCIA E O MEDO DO CRIME: ANÁLISE MULTIDIMENSIONAL}

A seguir passaremos a analisar os fatores determinantes do medo tendo em vista as sete dimensões discutidas anteriormente envolvendo a percepção da população sobre a atuação da polícia. Faremos esta análise em três partes devido à diferença dos resultados encontrados para estes três contextos: (a) em casa, (b) no bairro onde a pessoa reside e (c) nos demais bairros da cidade.

As dimensões analisadas foram: (1) presença de policiamento (motorizado ou a pé); (2) presenciar a atuação da polícia; (3) estabelecer contato com a polícia; (4) confiar na polícia; (5) qualidade do serviço prestado pelas polícias; (6) qualidade da conduta dos policiais e (7) violência e corrupção policial. Trazemos em anexo tabelas que identificam o grupo crítico em relação ao medo e o respectivo grupo de re- 
ferência, assim como a razão de chance desta relação. Por exemplo, as pessoas que moram em regiões onde não têm policiamento a pé têm $34,8 \%$ mais medo do que as pessoas que moram em regiões onde este policiamento existe e é de ótima ou boa qualidade (Anexo I). Marcamos em tom escuro as relações que caminham em sentido contrário ao esperado pelas nossas hipóteses. Por exemplo, em se tratando da pessoa sozinha em casa, presenciar a apreensão de armas e drogas pela polícia traz medo. Por fim, marcamos em tom claro os fatores mais significativos na produção do medo.

Nossa hipótese 1 - a presença de policiamento reduz o medo - foi comprovada de forma plena. A presença do policiamento nas vias públicas, especialmente o policiamento a pé, leva à redução do medo nos contextos da casa, do bairro onde reside e nos outros bairros. Quando a pessoa está em casa acompanhada, o impacto da presença e do policiamento é menor. O policiamento a pé também diminui o medo das pessoas nos outros bairros durante a noite. Já a presença de policiamento motorizado nos outros bairros à noite não apresentou relação estatística significativa.

Para a nossa hipótese 2 - entrar em contato com a polícia leva à redução do medo - encontramos mais evidências no sentido de rejeitar a hipótese do que comprová-la. Das 98 relações avaliadas, encontramos 37 que negaram a hipótese, 22 que comprovaram e 39 em que não encontramos resultados estatisticamente significativos (vide anexos). No contexto da casa, predominou as respostas não significativas e fora de casa predominaram as respostas que negaram a hipótese. Dentre os fatores que caminharam segundo previa nossa hipótese, destacamos apenas que ter entrado em contato com a polícia em uma revista pessoal reduz o medo. Por outro lado, em sentido contrário, destacamos que presenciar perseguição policial aumenta o medo.

Nossa hipótese 3 - a confiança na polícia reduz o medo - foi confirmada de forma plena em praticamente todos os contextos analisados. Apenas para as situações nas quais a pessoa está em outros bairros à noite não encontramos uma relação estatisticamente significativa entre medo e confiança na Polícia Civil.

Para a nossa hipótese 4 - qualidade do serviço prestado pela polícia reduz do medo da população - encontramos mais evidências no sentido de rejeitar a hipótese do que de comprová-la. No total de 35 
relações avaliadas, encontramos sete que negaram nossa hipótese, 10 que comprovaram a hipótese e um total de 18 em que não encontramos resultados estatisticamente significativos (vide anexos). Não encontramos relação significativa entre a boa avaliação dos serviços de polícia e o medo no contexto da casa. Já fora de casa, seja no próprio bairro ou em outros, predominaram as respostas que corroboraram com a nossa hipótese. Dentre os serviços prestados pelas polícias, a qualidade do atendimento emergencial se mostrou fundamental para controlar o medo. Nenhum fator se destacou caminhando no sentido contrário ao estabelecido pela nossa hipótese.

Para a nossa hipótese 5 - a qualidade da conduta dos policiais reduz o medo - encontramos mais evidências no sentido de rejeitar a hipótese do que de comprová-la (vide anexos). No total de 49 relações avaliadas, encontramos 19 que negaram nossa hipótese, 15 que comprovaram a hipótese e um total de 15 em que não encontramos resultados estatisticamente significativos. Uma boa avaliação da conduta dos policiais não impactou o medo no contexto da casa. Nos contextos de fora de casa predominaram as respostas não significativas. Dentre os fatores que caminharam segundo previa nossa hipótese, podemos destacar apenas que, no contexto da casa e nos outros bairros da cidade, as pessoas que têm mais medo são as que acreditam que os policiais não estão preparados para usar arma de fogo. Por outro lado, em sentido contrário ao esperado, observamos nos três contextos analisados que as pessoas que acreditam que os policiais sabem agir em situação de risco e perigo são as que mais têm medo.

Por fim, em relação à nossa hipótese 6 - a percepção da existência de violência e corrupção policial aumenta o medo - encontramos motivos para corroborá-la quando se trata apenas do medo em casa e levando em conta especificamente a extorsão praticada pela polícia. Em todos os demais contextos, a nossa hipótese deve ser negada. Por outro lado, em sentido contrário ao esperado, verificamos que presenciar a agressões ou ameaças de policiais reduziu o medo nos outros bairros da cidade.

\section{CONCLUSÃO}

As análises realizadas neste artigo com os dados trazidos pela Pesquisa Distrital de Vitimização (2015) confirmam em parte nossas hipóteses construídas a partir da literatura especializada. Dentre as 
dimensões tratadas para representar a atuação da polícia - presença e qualidade do policiamento, presenciar a atuação da polícia sendo cliente ou não do serviço prestado, qualidade do serviço e da conduta dos profissionais, confiança na polícia e a violência policial - duas se destacaram: a mais importante para controle do medo é a presença e qualidade do policiamento, sendo que o policiamento a pé é importante para controlar o medo nas vias públicas e o policiamento em viatura é importante para controlar o medo em casa; e a segunda dimensão mais importante foi a confiança da população na polícia, especialmente na Polícia Militar.

Presenciar a atuação da polícia, estabelecer contato com a polícia, avaliar positivamente o serviço policial e a conduta dos policiais mostraram baixo impacto na redução do medo. Entre estas dimensões, a mais forte foi estabelecer contato com a polícia e a menos forte foi presenciar a atuação da polícia. Por fim, o impacto da violência policial no medo também mostrou ser fraco na produção do medo.

Presenciar a atuação da polícia mostrou ser algo pouco importante para o controle do medo, especialmente em casa, pois predominaram as situações em que a relação entre os fatores analisados e o medo não é estatisticamente significativa. Pelo contrário, presenciar perseguição policial ou estabelecer contato com a polícia para intervenção em crime está relacionado com aumento do medo. O único fator que mostrou ser importante para produzir sensação de segurança foi o estabelecimento de contato com a polícia em uma revista pessoal. Também a qualidade do serviço mostrou ser pouco importante para o controle do medo, novamente predominando as relações não significativas estatisticamente. Neste contexto, cabe ressaltar apenas a importância da qualidade do atendimento emergencial para controlar o medo fora de casa, seja no bairro onde a pessoa reside ou nos demais bairros da cidade. Por fim, a qualidade da conduta dos policiais militares mostrou ter um resultado predominantemente contrário ao que esperávamos. Apenas dois fatores se destacaram em todos os contextos analisados, um no sentido esperado (as pessoas que acreditam que os policiais não estão preparados para usar arma de fogo são as que têm mais medo) e outra no sentido contrário ao esperado (as pessoas que acreditam que os policiais sabem agir em situação de risco e perigo são as que mais têm medo). 
No tocante ao impacto da presença de violência policial na vizinhança, cabe ressaltar aqui que identificamos a necessidade de distinguirmos o tipo de violência. Se, por um lado, a presença de policiais extorquindo promove medo especialmente no ambiente doméstico e nas vias públicas do bairro onde reside durante o dia, por outro lado, a presença de policiais agredindo ou ameaçando promove a redução do medo de forma generalizada. Cabe aqui salientar que não tratamos do fato de o indivíduo ter sido vitimado pela violência policial, mas do fato de ele ter conhecimento sobre a presença na vizinhança de policiais atuando de forma violenta.

Uma das possíveis reflexões que podemos fazer a partir dos resultados encontrados é de que, por um lado, a pessoa quer ser atendida com cortesia, de forma segura e dentro da lei e, por outro, ela compreende que a atuação da polícia está muitas vezes associada a condutas arbitrárias, violentas e preconceituosas para garantir a efetiva solução do problema. Ou seja, há uma certa tolerância com a arbitrariedade e violência policial.

Esta combinação de fatores aparentemente contraditórios termina resultando na produção da sensação de segurança em decorrência de dois fatores. Primeiro, a opinião pública de que os policiais têm uma conduta violenta não tem como fundamento exclusivamente a conduta dos profissionais do próprio DF. Esta opinião termina resultando do contato com notícias veiculadas pela mídia a respeito da violência policial em outras cidades do Brasil. Segundo, justamente devido à exiguidade da presença da violência policial no DF, esta termina sendo percebida como algo que deve estar ocorrendo com pessoas desconhecidas e de fora do círculo social da pessoa entrevistada, que muitas vezes são percebidas como "marginais" que estão recebendo aquilo que merecem em termos da conduta da polícia.

Por fim, a conclusão a que chegamos sobre o impacto da violência policial termina completando o argumento desenvolvido acima em relação ao fato de a conduta policial violenta produzir segurança. Quando a pessoa sabe que na sua vizinhança ocorreu um ato de violência policial, esta passa a vitimar pessoas conhecidas e não aquele "marginal" que estaria sendo tratado da forma que merece. A pessoa passa, então, a se ver como uma possível vítima da atuação da polícia. Por fim, cabe ainda salientar que a conduta violenta da polícia 
que gera mais medo é a extorsão, pois termina sendo algo que a pessoa se vê com menos chance de conseguir escapar.

Estas conclusões trazem importantes subsídios, não apenas para o debate intelectual sobre qual o papel da polícia diante do medo da população sobre o crime, mas também para o desenho de políticas públicas sobre o tema.

(Recebido para publicação em fevereiro de 2018)

(Reapresentado em janeiro de 2019)

(Aprovado em fevereiro de 2019) 


\section{REFERÊNCIAS BIBLIOGRÁFICAS}

BEATO FILHO, Cláudio. C.; SILVA, Braulio. F. A. e TAVARES, Ricardo. (2008), “Crime e estratégias de policiamento em espaços urbanos". Dados, Vol. 51, n. 3, pp. 687-715.

BENNETT, Trevor. (1991), "The effectiveness of a police initiated fear reducing strategy". British Journal of Criminology, Vol. 31, pp. 1-14.

BORGES, Doriam. (2011), O medo do crime na cidade do Rio de Janeiro: uma análise sob a perspectiva das crenças de perigo. Curitiba, Appris.

BOX, Steven; HALE, Chris e ANDREWS, Glen. (1988), "Explaining fear of crime". British Journal of Criminology, Vol. 28, pp. 340-356.

CALDEIRA, Teresa. P. R. (2000), Cidade de muros: crime, segregação e cidadania em São Paulo. São Paulo: Editora 34/Edusp.

CHADDEE, Derek; et al. (2016), "Fear of Crime: the influence of general fear, risk, and time perspective". Journal of Interpersonal Violence, Vol. 34(6), pp. 1-23.

COHEN, Lawrence e FELSON, Marcus. (1979), "Social changes and crime trends: a routine activity approach". American Sociological Review, Vol. 44, pp. 588-608.

DAMMERT, Lucia. (2016), "Confianza en la Policía em Chile: un arma de doble filo". Civitas, Vol. 16(4), pp. 575-594.

DAVIS, Robert C. e HENDERSON, Nicole J. (2003), "Willingness to Report Crime: the role of ethnic group membership and community efficacy". Crime and Delinquency, Vol. 49, pp. 564-580.

FRANKLIN, Cortney e FRANKLIN, Travis. (2009), "Predicting fear of crime: considering differences across gender". Feminist Criminology, Vol. 4(1), pp. 83-106.

GOLDSTEIN, Herman. (1990), Problem oriented policing. New York: McGraw-Hill.

GOODEY, Jo. (1997), "Boys don't cry: masculinities, fear of crime and fearlessness". British Journal of Criminology, Vol. 37, pp. 401-419.

GRAY, Emily; JACKSON, Jonathan. e FARRALL, Stephen. (2008), "Reassessing the fear of crime". European Journal of Criminology, Vol. 5(3), pp. 363-380.

HALE, Chris. (1996), "Fear of crime: a review of the literature". International Review of Victimology, Vol. 4, pp. 79-150.

HAWDON, James; RYAN, John e GRIFFIN, Sean. P. (2003), "Policing tactics and perceptions of police legitimacy". Police Quarterly, Vol. 6, pp. 469-491.

KILLIAS, Martin e CLERICI, Christian. (2000), "Different measures of vulnerability in their relation of different dimension of fear of crime". British Journal of Criminology, Vol. 40, pp. 437-450.

MACHADO, Lia Z; BORGES, Antonadia; MOURA, Cristina P. (2014), A cidade e o medo. São Paulo: Francis.

MARKOWKIZ, Fred E.; et al. (2001), "Extending Social Disorganization Theory: modeling the relationship between cohesion, disorder and fear". Criminology, Vol. 39, pp. 293-320. 


\section{A Polícia e o Medo do Crime no Distrito Federal}

OLIVEIRA JR; Almir e ALENCAR, Rafael A. (2015), “A predisposição para chamar a polícia: um estudo sobre a percepção do desempenho e da confiabilidade das instituições policiais". Revista Brasileira de Segurança Pública, Vol. 9(1), pp. 158-170.

OLIVEIRA Jr. Almir. (2011), “Dá para confiar nas polícias? Confiança e Percepção Social das Polícia no Brasil". Revista Brasileira de Segurança Pública, Vol. 9, pp. 6-23.

PANTAZIS, Christina. (2000). "Fear of Crime, vulnerability and poverty". British Journal of Criminology, Vol. 40, 414-436.

RODRIGUES, Corine D. e OLIVEIRA, Valéria C. (2012), “Medo do crime e desordem: uma análise da sensação de insegurança e do risco percebido na capital de Minas Gerais". Teoria \& Sociedade, Vol. 20, pp. 156-184.

SACCO, Vincent F. (1993), "Social support and fear of crime". Canadian Journal of Criminology, 35, pp. 187-196.

SAMPSON, Robert J. e GROVES, W. Byron. (1989), "Community structure and crime: testing social desorganization theory". American Journal of Sociology, 94, pp. 774-802.

SCHAFER, Joseph; HEUBNER, Beth e BYNUM, Timothy. (2006), "Fear of crime and criminal victimization: gender based contrasts". Journal of Criminal Justice, pp. 285-301.

SCHEIDER, Matthew C.; ROWELL, Tawandra e BERDIZIAN, Veh. (2003), "The impact of citizen perception of community policing on fear of crime: findings from twelve cities". Police Quarterly, Vol. 6, pp. 363-386.

SILVA, Gelson e BEATO FILHO, Cláudio C. (2013), “Confiança na polícia em Minas Gerais: o efeito da percepção de eficiência e do contato individual". Opinião Pública, Vol. 19(1), pp. 118-153.

TRAJANOWICS, Robert C. (1986), "Evaluating a neighborhood foot patrol program". In: Community crime prevention: does it works? Londres: SAGE.

TSELONI, Andromachi e ZARAFONITOU, Christina. (2008), “Fear of crime and victimization: a multivariate multilevel analysis of competing measurements". European Journal of Criminology, Vol. 5(4), pp. 387-409.

WARR, Mark e ELLSON, Christopher. (2000), "Rethinking social reactions to crime: personal and altruistic fear in family households". American Journal of Sociology, Vol. 106(3), pp. 551-578.

WINKEL, Frans W. (1988), "The police and reducing fear of crime: a comparison of the crime-centered and the quality of life approaches". Police Studies, Vol. 11, pp. 183-189. 


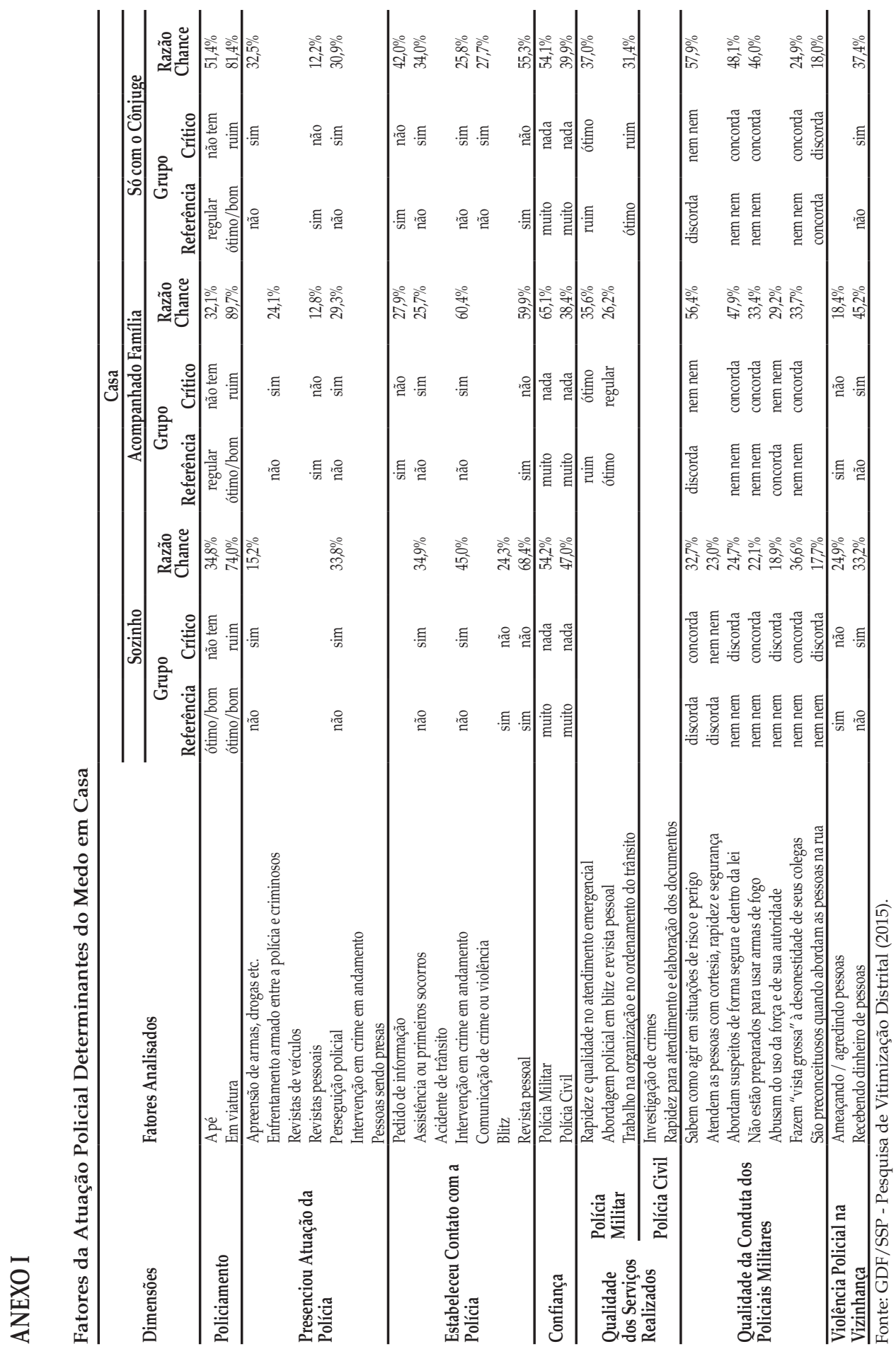

DADOS, Rio de Janeiro, vol.62(1):e20180032, 2019. 


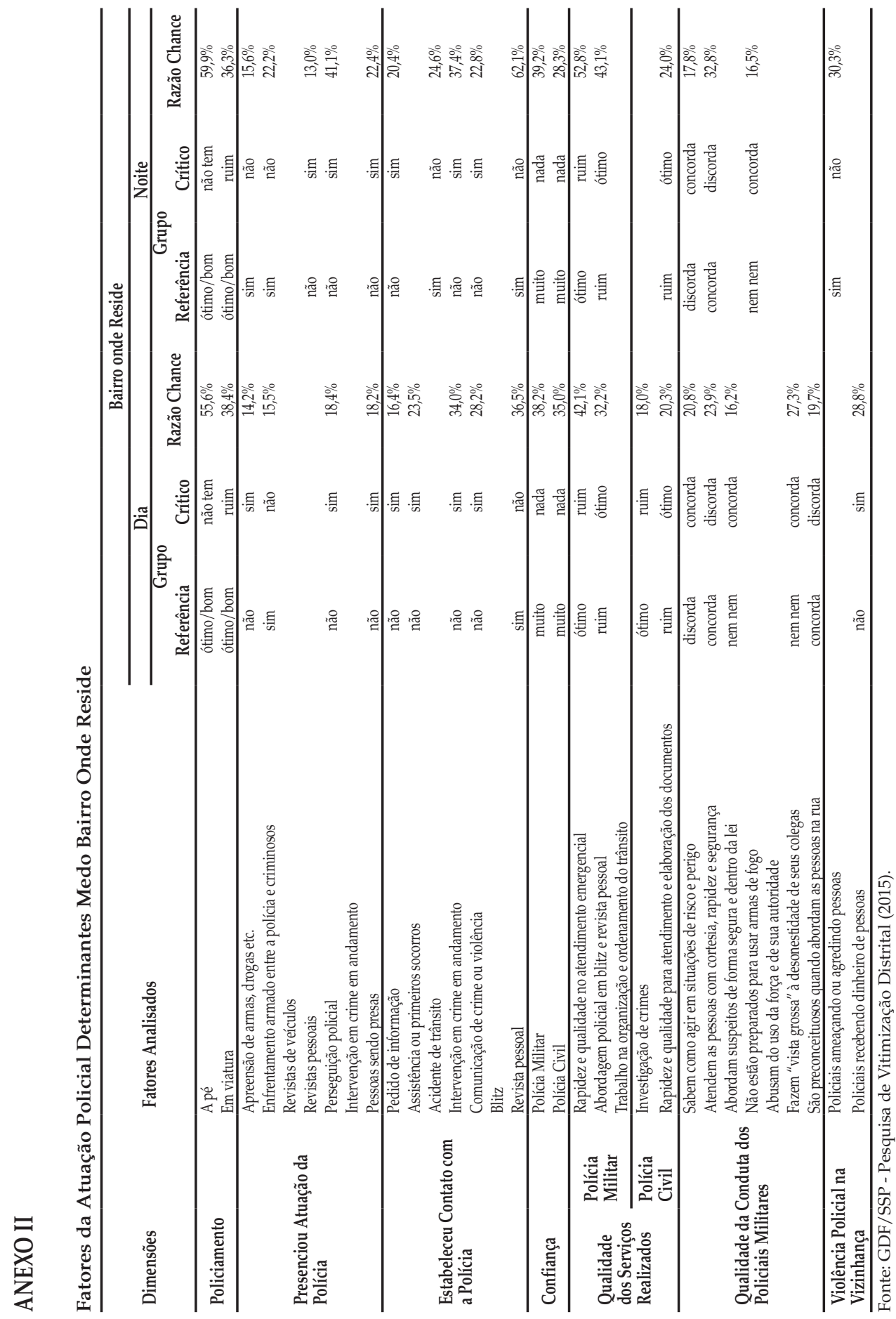




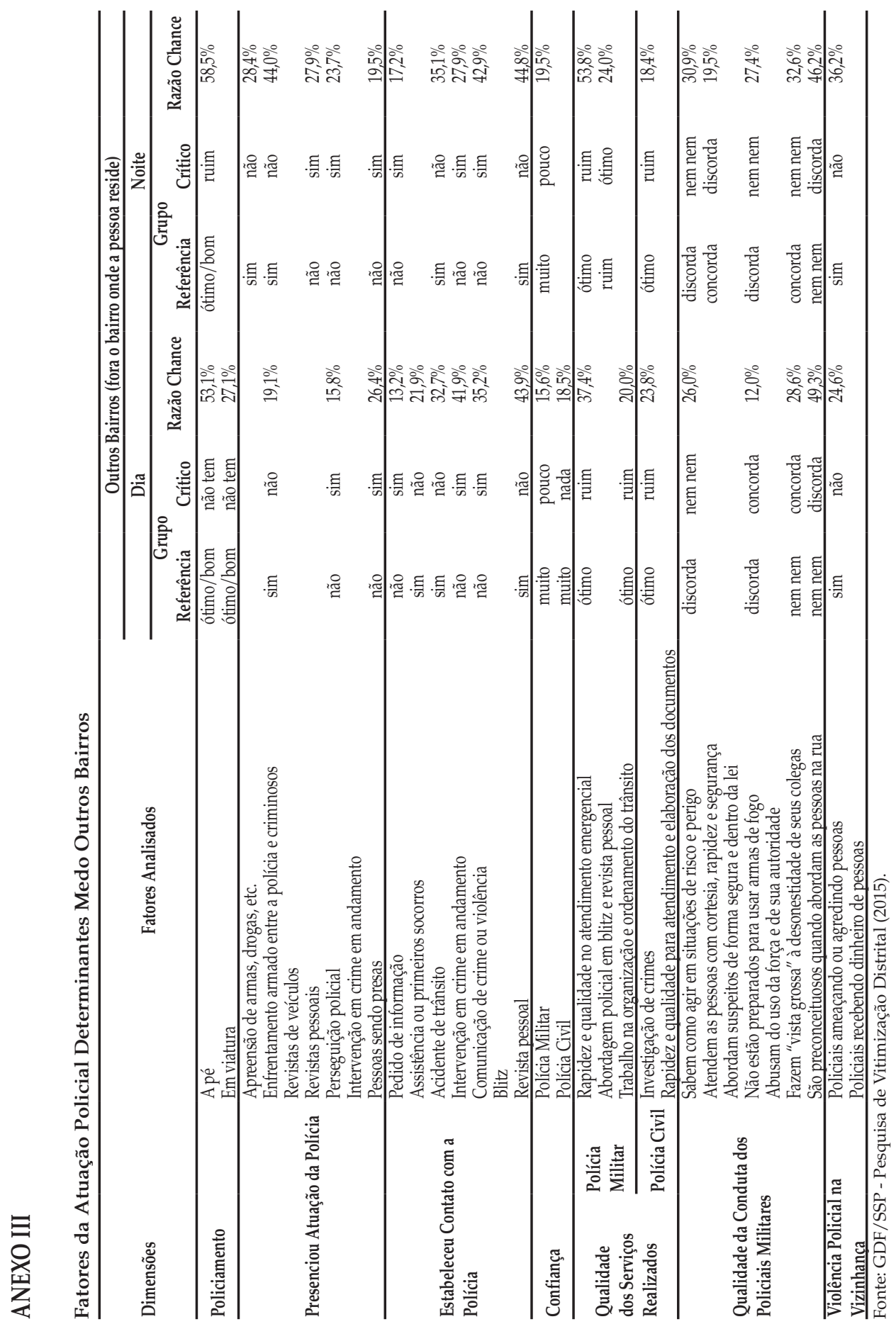




\section{RESUMO}

\section{A Polícia e o Medo do Crime no Distrito Federal}

Neste artigo, analisamos a relação entre as percepções que as pessoas fazem da atuação da polícia e o medo do crime. A atuação da polícia foi avaliada a partir das seguintes dimensões: presença e qualidade do policiamento nas vias públicas, presenciar atuação da polícia, estabelecer contato com a polícia, confiança na polícia, qualidade da conduta dos policiais, qualidade do serviço prestado pela polícia e violência policial. Para isso utilizamos os dados da Pesquisa Distrital de Vitimização, realizada em 2015, pela Secretaria de Segurança Pública do Distrito Federal. Verificou-se que o aspecto mais importante para a redução do medo do crime é a presença do policiamento, especialmente do policiamento a pé. Outro aspecto importante para redução do medo é a confiança da população na polícia, especialmente na Polícia Militar. Por fim, identificamos que a população legitima a violência policial quando direcionada para o outro, especialmente aquele em relação ao qual existe preconceito, mas a violência não é legítima quando a própria pessoa pode ser atingida.

Palavras-chave: medo do crime; polícia; confiança; violência policial; Distrito Federal

\section{ABSTRACT \\ Police and Fear of Crime in Distrito Federal}

In this article, we analyze the relationship between people's perceptions of police action and fear of crime. Police action was assessed based on the following aspects: presence and quality of policing on public roads, witnessing police actions, establishing contact with the police, trust in the police, quality of police conduct, quality of police services and police violence. For this, we used the data from the District Victimization Survey, conducted in 2015 by the Secretary of Public Security of the Federal District. It has been found that the most important aspect for reducing fear of crime is the presence of police, especially foot patrol. Another important factor to reduce fear is the confidence of the population in the police, especially in the Military Police. Finally, it is clear that the population legitimizes police violence when directed to the other, especially the one in relation to which there is prejudice, whereas violence is not perceived as legitimate when the person himself can be victimized.

Keywords: fear of crime; police; trust; police violence; Distrito Federal 


\section{RÉSUMÉ \\ La Police et la peur du crime au Distrito Federal}

Dans cet article, on analyse la relation entre les perceptions de l'action policière et de la peur du crime. L'action de la police a été évaluée en fonction des dimensions suivantes: présence et qualité du maintien de l'ordre public dans les rues; voire l'action de la police; établir contact avec la police; confiance à la police ; qualité de la conduite de la police; qualité du service fourni par la police; et la violence perpétrée pour les agents de police. Pour cela, on a utilisés les données de l'enquête Pesquisa Distrital de Vitimização, menée en 2015, par la Secretaria de Segurança Pública do Distrito Federal. On a constaté que l'aspect le plus important pour réduire la peur du crime est la présence de la police, surtout quand les gardes se placent à pied. Un autre aspect important pour réduire la peur c'est la confiance de la population à la police, en particulier à la Police Militaire. Enfin, on a réussi que la population légitime la violence policière lorsqu'elle est dirigée vers un autre, en particulier ce pour lequel il y a déjà une culture de préjudice, mais que la violence n'est pas légitime lorsque la personne elle-même peut être l'objet.

Mots-clés: peur du crime; la police; la confiance; violence policiel; Distrito Federal

\section{RESUMEN}

\section{La Policía y el Miedo al Crimen en el Distrito Federal}

En este artículo, analizamos la relación entre las percepciones que las personas tienen de la actuación de la policía y el miedo al crimen. La actuación de la policía fue evaluada a partir de las siguientes dimensiones: presencia y calidad de la vigilancia en las vías públicas, presenciar la actuación de la policía, establecer contacto con la policía, confianza en la policía, calidad de la conducta de los policías, calidad del servicio prestado por la policía y violencia policial. Para eso, utilizamos los datos de la Encuesta Distrital de Victimización, realizada en 2015 por la Secretaría de Seguridad Pública del Distrito Federal. Se verificó que el aspecto más importante para la reducción del miedo al crimen es la presencia de la vigilancia, especialmente de la vigilancia a pie. Otro aspecto importante para la reducción del miedo es la confianza de la población en la policía, especialmente en la Policía Militar. Finalmente, identificamos que la población legitima la violencia policial cuando se encuentra direccionada para el otro, especialmente aquel sobre el cual existe discriminación, pero la violencia no se considera legítima cuando la propria persona puede ser afectada.

Palabras Clave: miedo del crimen; policía; confianza, violencia policial; Distrito Federal 